Original Article

\title{
Teaching of Veterinary Parasitology to University students in Trinidad, West Indies; are our local wildlife species neglected?
}

\author{
Ensino de parasitologia veterinária para estudantes universitários em Trinidad, Índias \\ Ocidentais; nossas espécies selvagens locais são negligenciadas?
}

\author{
K. R. Jones ${ }^{\mathrm{a}, \mathrm{b} *}$ (1) and G. W. Garcia ${ }^{\mathrm{a}}$ (D) \\ aUniversity of the West Indies - UWI, Faculty of Food and Agriculture - FFA, Department of Food Production - DFP, St. Augustine Campus, St. \\ Augustine, Trinidad and Tobago \\ bUniversity of the West Indies - UWI, School of Veterinary Medicine - SVM, Faculty of Medical Sciences - FMS, Department of Basic Veterinary \\ Sciences - DBVS, Mt. Hope Campus, Mt. Hope, Trinidad and Tobago
}

\begin{abstract}
Parasites of veterinary importance have been heavily focused on domesticated livestock that was introduced into the neo-tropics. The text used in the teaching parasitology to veterinary students in Trinidad has only investigated the parasites of domesticated species. In the reviewed veterinary parasitology text no mention was made on the parasites that affect wild neo-tropical animals. Information on wild neo-tropical animals had to be sourced from texts on the management of wild life animals in the Neotropics. The texts that were reviewed in this document spanned from the mid-1950s to 2020. The information presented in this review reveals the exhaustive work done on the parasites of domesticated species but also revealed little information on neo-tropical animals with the potential for domestication. In conclusion, this review reveals the gap of information that is missing from parasitology texts used in the teaching of veterinary students. In the future these parasitology texts can be revised to include chapters on the parasites of neo-tropical animals with the potential for domestication. At present students that graduate from the veterinary parasitology course has little information on the parasites of animals which are present in their 'backyards'.
\end{abstract}

Keywords: Neo-tropics, livestock, Trinidad, domestication, veterinary parasitology.

\begin{abstract}
Resumo
Parasitas de importância veterinária têm se concentrado fortemente em animais domésticos que foram introduzidos na região neotrópica. O texto usado no ensino de parasitologia para estudantes de veterinária em Trinidad investigou apenas os parasitas de espécies domesticadas. No texto de parasitologia veterinária revisado, nenhuma menção foi feita sobre os parasitas que afetam os animais selvagens neotropicais. As informações sobre animais selvagens neotropicais tiveram que ser obtidas a partir de textos sobre o manejo de animais selvagens nos Neotrópicos. Os textos revisados neste documento vão de meados da década de 1950 até 2020. As informações apresentadas nesta revisão revelam o trabalho exaustivo realizado sobre os parasitas de espécies domesticadas, mas também revelaram poucas informações sobre animais neotropicais com potencial para domesticação. Em conclusão, esta revisão revela a lacuna de informação que existe nos textos de parasitologia utilizados no ensino de estudantes de veterinária. No futuro, esses textos de parasitologia podem ser revisados para incluir capítulos sobre os parasitas de animais neotropicais com potencial para domesticação. Atualmente, os alunos que se formam no curso de parasitologia veterinária têm poucas informações sobre os parasitas de animais que estão presentes em seus "quintais".
\end{abstract}

Palavras-chave: Neo-tropics, pecuária, Trinidad, domesticação, parasitologia veterinária.

\section{Introduction}

Parasitology is defined as the study of parasitic interactions amongst organisms (Lapage, 1954). As veterinarians our understanding of the parasites of animals is of critical importance. Parasites infect both domesticated and non-domesticated animals in a variety of ways. The world can be divided into different ecological zones. This document attempts to focus on animals present in the

Neo-tropical zone. These Neo-tropical animals can be classified into three groups based on their origins.

The first group are animals which were introduced into the Neo-tropics from European invaders. These animals are cattle (Bos indicus/ Bos Taurus), sheep (Ovis aries), goat (Capra hircus), pigs (Sus sucrofa), horses (Equus caballus) and chickens (Gallas domesticus) (Jones and Garcia, 2018). 
The second group of animals are domesticated animals that originated in the Neo-tropics. These animals include turkeys (Meleagris gallapavo), ducks (Cairina moschata), chincillas (Chinchilla lanigera), guinea pigs (Cavia porcellus), South American camelids (Lama glama) (Jones and Garcia, 2019).

The third group of animals include non-domesticated/ wild neo-tropical animals with the potential for domestication. These animals include the agouti (Dasyprocta leporina), lappe (Agouti paca), manicou (Didelphis marsupialis insularis), capybara (Hydrochoerus hydrochaeris), red brocket deer (Mazama americana) and collared peccary (Peccari tajacu/Tayassu tajacu) (Jones et al., 2019). There has been heavy focus on the parasites that affect domesticated livestock (Soulsby, 1982).

However, there is little information on the parasites that affect Non-domesticated Neotropical mammals. Recently, parasites of these non-domesticated animals were reviewed with few reports of clinical disease (Jones et al., 2019). However, lack of clinical signs does not mean that the animals are unaffected. Parasites of animals can be classified by the environment in which they can be found on their host, either endoparasites (parasites found within the host) or ectoparasites (parasites found outside on the skin, hair and fur) (Hendrix and Robinson, 2016).

Endoparasites can be further broken down into blood parasites or parasites found in various organs/tissues. Taxonomically, parasitism can be broken down into helminths (worms), protozoa, insects (dipterans) and arachnids (ticks) (Zajac and Conboy, 2017). Parasites have detrimental effect for livestock animals as they remove essential nutrients from the animals; they cause tissue damage/ injury and introduce other pathogenic organisms into the animals (Soulsby, 1982; Krull, 1968; Lapage, 1954). The objective of this short note is to highlight the information given to veterinary students in Trinidad and Tobago on parasitology. This paper viewed the reference texts that were used in the teaching and attempts to categorize the information accessed.

\section{Parasites of Veterinary Importance}

The material used in teaching veterinary parasitology to students in Trinidad was searched using library as well online sources. The reference books used were analysed based on content and structure. The books were divided into parasites of veterinary importance based on predilection site (Ectoparasites, Endoparasites and blood parasites) (Soulsby, 1982, Zajac and Conboy, 2017). Other reference texts have also divided its content based on the animal (host) involved. (Urquhart et al., 1996). However, in the analysis of the text there was no mention made to parasites wild Neo-tropical animals. Some texts made reference to wild animal parasites of animals which originated from North America and Europe (Soulsby, 1982).

In light of the dearth of information on the parasites of wild neo-tropical animals a further search was done for reference material on diseases which affects wildlife at a global perspective. There were only a few books which focused on the health and management of wild neotropical animals (Fowler, 1998; Fowler and Cubas, 2001).
These books were written by authors who were located in the neo-tropics. However, there was little information on these animals and treatments were similar to those used for domesticated livestock (Fowler, 1998). Recently, Endoparasites of selected wild neo-tropical animals was conducted and data showed that parasites had little clinical effects on these animals (Jones et al., 2019). The remaining sections of this review were broken down into the parasites which were mentioned in the text of veterinary parasitology text (mainly focuses on domestic animals and wild/exotic parasites of European and North American origin) and wildlife management.

\section{Ectoparasites}

\subsection{Domesticated animals}

\subsubsection{Mites}

This subsection will discuss mites which affect domesticated species (dogs, cat, livestock, horses, avian and exotic species). Sarcoptes scabiei commonly known as the 'itch mite' affects wide range of domestic species. It is transmitted by direct contact with an infected animal or fomite. Identification can be done on scab material digested in sodium hydroxide and examined under a microscope (Zajac and Conboy, 2017) Mange caused by Sarcoptes scabiei are highly pruritic and is accompanied by alopecia, hyperkeratosis and crust formation. Sarcoptes scabiei can be transmitted to humans which makes it a disease of zoonotic importance.

The ear mange mite of rodents (Notoedres spp.) can be found on cats, rodents, rabbits and some wild animals. This mite usually affects the head first but can also be found on other parts of the body. N. cati is found on cats and mites can be seen with deep skin scrapings. Lesions are similar to those seen with sarcoptic mange (Zajac and Conboy, 2017). In birds, Knemidokoptes spp. (scaly leg or scaly face mite) causes clinical disease in domestic poultry and pet birds. Affected areas include the face and legs, transmission occurs via direct contact with fomites or infected birds. Lesions are usually exudative and eventually harden into a crust. Proliferative lesions may cause trauma and disfigurement which can lead to the death of the animal.

In rodents (guinea pigs and rats) mites of the Trixacarus spp. have been found on the head, neck and back. T. caviae have been found on guinea pigs whilst $T$. diversus has been seen on rats. Infection is associated with pruritus, hyperkeratosis and alopecia. This disease is somewhat zoonotic as humans in contact with infected guinea pig may develop transient lesions. Another mite that affects a wide range of hosts is Psoroptes spp. P. ovis causes psoroptic mange in ruminants and $P$. cuniculus is found in rabbits. These parasites are transmitted by direct contact but do not burrow into the skin (Zajac and Conboy, 2017). In severe cases, lesions in rabbits extend beyond the ear to the face, neck and back. Infestation leads to exudative dermatitis and fur loss. Chorioptes bovis (common names: foot mange, leg mange, itchy heel) affects rabbits, horses and ruminants. Symptoms are asymptomatic but in some cases of clinical disease it is similar to Psoroptes spp. 
The ear mite commonly found in dogs, cats and ferrets is Otodectes cyanotis. This mite infestation produces a black "coffee brown" exudate and is diagnosed by otoscopy or microscopy of aural exudate. These mites primarily cause otitis externa but in heavy infestation it may spread to the face neck and back. The follicle mite also known as Demodex is found in many hosts (Zajac and Conboy, 2017). It has been found on dogs, cats, pigs, horses, cattle, goat, sheep, laboratory animals and humans. Usually infested animals are asymptomatic but generalized demodectic mange is seen with dogs with immunodeficiency. Demodectic mange is rarely seen in livestock.

Cheyletiella spp. is a mite commonly called walking dandruff that affects rabbits (C. parasitovorax), dogs ( $C$. yasguri) and cats ( $C$. blakei). Transmission occurs via direct contact or fomites (such as fleas). Cheyletiella is a fur mite and does not inhabit the skin and only superficial skin scrapings are needed for identification. Most animals infected as asymptomatic but young animals are most likely to be show clinical signs which include pruritus and crusting (Zajac and Conboy, 2017). Lynxacarus radovskyi is usually found on the tail head, tail tip and perineum of cats. These mites are usually found in Australia, southern United States, Caribbean and Hawaii. The entire life cycle is spent on the hair of host with eggs being attached to the hairs. These mites are laterally flattened and heavy infestation can lead to a poor hair coat of the cats' entire body.

Leporacarus gibbus affects rabbits and is found throughout the fur. Transmission occurs through direct contact but is usually asymptomatic even if large numbers are present. In guinea pigs, Chirodiscoides caviae is found attached to hairs and is transmitted through direct contact with infested individual or fomite. Chirodiscoides caviae is also considered non-pathogenic. Rats and mice, can be host to a variety of fur mites. Some animals may tolerate high numbers and remain asymptomatic (Zajac and Conboy, 2017). However, other animals may have pruritus, erythema, alopecia and hyperkeratosis. Secondary bacterial infection can also occur in some cases. These mites that can cause the above signs in rats and mice are Mycoptes musculinus, Myobia musculi and Radfordia spp. The tropical rat mite (Ornithonyssus bacoti) is found on rodents and on occasion human and other animals. The adults lay eggs in the environment and are only present on the host for feed. In large numbers the blood feeding mite can cause anaemia, debilitation and death (Zajac and Conboy, 2017).

Mites which are found on avian species are Ornithonyssus sylviarum (Northern fowl mite), O. bursa (Tropical fowl mite) and Dermanyssus gallinae (Red fowl mite). These mites cause scabbing and feather matting. In severe cases anaemia, decreased production and death can occur. 0 . sylviarum spends its entire life on the host where adults and eggs can be found in the feathers. 0 . bursa spends most of its time off the host whilst $D$. gallinae visits the host at night to acquire blood meals (Zajac and Conboy, 2017).

\subsubsection{Ticks}

Ticks can be divided into two families; hard ticks (Ixodidae) and soft ticks (Argasidae). Hard ticks are of greater veterinary importance as they are vectors for viral, bacterial and protozoal pathogens. In addition, hard ticks can cause tick paralysis and tick toxicosis. The hard ticks will be evaluated first and the soft ticks evaluated later. Amblyomma spp. of ticks can be found in a wide variety of domestic and wild animals (Zajac and Conboy, 2017). This tick is a three host tick, meaning at each stage of its life cycle a new host must be found. Various species are found in the tropical and sub-tropical region; A. americanum (lone star tick), A. maculatum (Gulf Coast tick), A. cajennense (Cayenne tick), A. herbraeum and A. variegatum. Due to the long mouth parts of this parasite attachment to host is painful causing secondary infection. There is also damage to the hides. These species of ticks are vectors for a number of pathogens which include; tularemia, Ehrlichia, Q- fever (A. americanum); Rickettsia rickettsia (A. maculatum); Cowdria, Rickettsia conori and Nairobi sheep disease (A. hebraeum, A. variegatum); heartwater (A. variegatum) (Zajac and Conboy, 2017).

In Asia, Europe and North Africa, Hyalomma spp. of ticks can be found on a wide variety of animals. This tick species is a two host tick and can cause diseases such as tick toxicosis. These ticks are also important vectors for Babesia, Theileria and Rickettsia spp. The Ixodes spp. of ticks is the largest genus of hard ticks that parasitize both domestic animals and humans. Some of these species include $I$. scapularis (deer tick), I. pacificus (western black-legged tick), I ricinus (castor bean tick), I. cantisuga (British dog tick), I. hexagonus (hedgehog tick), I. rubicundus (South African paralysis tick) and I. holocyclus (Australian paralysis tick) (Zajac and Conboy, 2017). These ticks are three host ticks that are vectors for Lyme borreliosis, Ehrlichia, looping ill and Babesia spp. These ticks can also cause dermatitis and tick worry due to the size of their mouth-parts.

Another tick that has three hosts as part of their life cycle is the Dermacentor spp. These ticks parasitize both wild and domesticated animals. Some of these species include: Dermacentor variabilis (American dog tick), D. andersoni (Zajac and Conboy, 2017) (Rocky Mountain wood tick), D. albipictus (Horse tick) and D. occidentalis (Pacific Coast tick). These ticks are vectors for Rocky Mountain spotted fever, anaplasmosis and babesiosis. The Dermacentor spp. are known to cause tick paralysis. Rhipicephalus spp. are important tick species that parasitizes livestock and dogs. These three host ticks transmit a large number of pathogens. These include: Babesia canis and Ehrlichia canis in dogs and theileriosis, babesiosis, anaplasmosis and Nairovirus in livestock. Several species of Rhipicephalus ticks are of veterinary importance, these include: $R$. sanguineus (brown dog tick), R. appendiculatus (brown ear tick), R. evertsi (redlegged tick), R. microplus (Tropical cattle tick), R. annulatus (Cattle fever tick) and R. decoloratus (blue tick) (Zajac and Conboy, 2017; Urquhart et al., 1996).

The last species of hard ticks to be discussed to the genus Haemaphysalis. These species of ticks parasitize rabbits (H. leporispalustris) and dogs ( $H$. leachi). These ticks are also three host ticks and transmit similar pathogens as discussed in other three host ticks. In large numbers these ticks contribute to poor condition and tick worry (Zajac and Conboy, 2017; Soulsby, 1982).

Soft host ticks of veterinary importance include Otobius megnini (Spinose ear tick), Argas spp. and Ornithodorus spp. Otobius megnini affects livestock and small animals and can cause severe inflammation and rupture of the ear drum 
of the host. Argas spp. is found in poultry and wild birds. These species are found in the environment and feed on the birds at night with heavy burdens causing decreases in production and health. Argas spp. also act as a vector for Borrelia anserine. Ornithodorus spp. is similar to Argas spp. in that they mainly feed of their host and night and live in the environment of the host. In large numbers these ticks can cause major blood loss (Zajac and Conboy, 2017).

\subsubsection{Lice}

Lice are insects that spend their entire life on its host. Lice can be divided into chewing (Mallophaga) or sucking (Anaplura) lice. Birds are only parasitized by chewing lice while mammals may have either chewing or sucking lice. Hematopinus spp. is sucking lice that parasitize mammals on the head, neck, tail and back. The various species that affects livestock are: $H$. suis (pigs), $H$. asini (horses), $H$. eurysternus (short nose sucking louse of cattle) and $H$. quadripertusus (tail louse of cattle) (Zajac and Conboy, 2017). Transmission of these parasites is via direct contact or fomites and infestation can produce anaemia, pruritus, self-inflected trauma and production losses.

Linognathus spp. are sucking lice which primarily parasitize on ruminants and dogs. The various species are L. pedalis (ovine foot louse), L. ovillus (ovine face louse), L. vituli (long-nosed cattle louse), $L$. africanus (bovine African blue louse) and L. setosus (dogs) (Zajac and Conboy, 2017). Animals infected with these parasites show similar clinical signs of previous sucking lice infestation. A louse specific to cattle is Selenopotes capillatus. This louse is a sucking louse which is known as the little blue cattle louse. Clinical signs are similar to other sucking lice. There are three species of human sucking lice. These are Pediculus humanus humanus (body louse), Pediculus humanus capita (head louse) and Phthirus pubis (pubic louse) (Zajac and Conboy, 2017). These lice are of veterinary importance as they are found in some pets that are in close contact with their human owners. In this case the client is informed of his/ her infestation. However, the lice do nothing to the pets and cannot survive or reproduce on domesticated animals.

Chewing lice which belong to the order Mallophaga that is of veterinary importance will now be discussed. Bovicola spp. which is the common biting louse parasitizes severe species of livestock which include: cattle (B. bovis), sheep (B. ovis), goat (B. caprae), horses (B. equi) and camelids ( $B$. breviceps) (Zajac and Conboy, 2017; Hendrix and Robinson, 2016). Chewing lice cause pruritus, dermatitis, production losses and secondary infections. Chewing lice do not cause anaemia as they are not blood sucking. The biting lice of dogs are Trichodectes canis and Heterodoxus spingera and that of cats is Felicola subrostratus. These lice have similar clinical signs as chewing lice stated previously. However, the dog louse has been seen as an intermediate host for the tapeworm Dipylidium caninum.

There are many species of avian lice, these parasites cause decrease production and loss of condition of animals seen with heavy infestation. Some common species are Menopon gallinae, Lipeurus caponis (wing louse of poultry) and Columbicula columbae (slender pigeon louse). With respect to exotic pet species, the guinea pig can be infested with Gliricola porcelli (biting louse), Gyropus ovidalis (sucking louse), Trimenopon jenningsi (sucking louse). Light infestations are asymptomatic but heavy infections animals show alopecia, unthriftiness and pruritus (Zajac and Conboy, 2017, Hendrix and Robinson, 2016).

\subsubsection{Fleas}

Fleas are wingless, laterally compressed insects where the adult stage is the only parasitic stage of the life cycle. Fleas are most likely encountered in dogs and cats but also live in a variety of animals. Fleas are more likely to move across host species if the preferred host is unavailable but may leave after obtaining a blood meal. The other stages of the life cycle can be found in the environment. The cat flea (Ctenocephalides felis felis) can be found on both cats and dogs, however, a similar species is also found in dogs (Ctenpcephalides canis) (Urquhart et al., 1996). Adult cat fleas seldom leave their hosts and female deposits egg on the host that fall off into the environment to hatch. Clinical signs such as pruritus can be seen in low level infestations but with large infestation pruritus, alopecia, anaemia and in some cases animals may develop flea bite hypersensitivity (even if fleas are in low numbers).

The human flea (Pulex irritans) is more commonly found on pigs, cats or dogs than on humans. Pulex simulans is a closely related species that affects dogs. Under intense infestation pruritus and intense irritation can be seen. However, Pulex spp. is a major vector for Yersina pestis (the Bubonic plague bacillus) and Rickettsia typhi (murine typhus). There are also species of fleas specific for rabbits and rodents but as with other flea species they may feed on other host if the primary host is unavailable (Zajac and Conboy, 2017; Hendrix and Robinson, 2017). Xenopsylla cheopsis (oriental rat flea) and Spilopsyllus cuniculi (rabbit flea) are the most documented species. Xenopsylla cheopsis only visits the host for feeding unlike the cat flea. Xenopsylla cheopsis are vectors for the bubonic plague, murine typhus, as well as tapeworms, trypanosomes and myxomatosis is rabbits. In birds, two fleas are of major veterinary importance. These are Echidophaga gallinacae (stick tight flea) commonly found on poultry and wild birds and Ceratophyllus spp. which is found on wild birds and chickens (Zajac and Conboy, 2017; Hendrix and Robinson, 2016). The stick tight is usually found on non-feathered areas, females are attached permanently to the host and eggs are deposited on the ground of in sores created by the attachment site. Clinical signs include anaemia, severe irritation, decreased production and restlessness.

\subsubsection{Flies}

Flies belonging to the dipteran order parasitize on animals and humans as adults or larvae. Parasitic adult flies are blood feeders whereas the larvae are referred to as bots. The larvae are found in specific locations within the body of the host. Maggots are also larval stages of flies but these are more associated with fly strike. In most cases of maggot infestations the adult flies are attracted to a wound on the animal where they would lay eggs on the fur of the animal close to the wound. 
The rodent bot fly (Cuterebra spp.) has their principle host as rabbit and rodents but humans, dogs and cats may also become infected. Larvae are found as subcutaneous cyst in various locations. Adult laid eggs around rodent holes. Larvae then crawl onto the animal and enter through facial orifices. After development, the larvae leave through the breathing orifice to pupate in the environment. Two to three bots present in rodents or dogs and cats are no associated with problems but secondary bacterial infections can be a potential problem (Zajac and Conboy, 2017; Hendrix and Robinson, 2016).

The stomach bot (Gastrophilus spp.) can be found in horses and other equids. There are several species present which include: G. intestinalis, G. nasalis and $G$. haemorrhoidalis. The adults deposit eggs on legs or face of horses. After hatching the larvae migrate to the tongue and mouth before moving into the stomach. Bots are passed in the faeces and pupate on the ground. Horses are able to tolerate small to moderate numbers of this bot. However, in large numbers they can cause gastric ulcerations. Hypoderma bovis and H. lineatum also known as the cattle warble or grub are primarily found in cattle but can also be found in horses (Urquhart et al., 1996). These parasites are found in the back of their host animal. The adult flies lay eggs unto the cattle where they hatch and penetrate the skin to migrate along the oesophagus or in tissue surrounding the spinal cord. Several months post development the larvae then migrate to the host's back and form subcutaneous nodules with a breathing hole. The larvae then emerge and pupate on the ground. Hypoderma causes various problems starting with the adult flies activity interferes with the grazing activity of cattle. Secondly, the migrating larvae cause necrotic tracts in the muscle tissue and the hide is damaged for leather production. Finally, if the larvae dies while in close proximity to the oesophagus or spinal cord, serious inflammatory reactions may occur leading to bloat or paralysis.

Larvae of Oestrus ovis are found in the nasal passages and sinuses of sheep and goat whilst Rhinoestrus larvae are found in horses. The adult female flies deposit larvae in or near the nasal passages where the larvae develop in the nasal passages. As development is completed the larvae fall out and pupate on the ground. Animals show minimal clinical signs with a few parasites but on some occasions a nasal discharge can be seen. Bots may occasionally wander to abnormal sites where they may cause serious disease. The human bot fly (Dermatobia hominis) can be found on cattle, humans, dogs and other wild and domestic animals. The adult female glues the eggs to various muscid flies and mosquitoes. When these organisms visit the host the Dermatobia larvae is deposited and enters the subcutaneous tissue. The species is most known as a human parasite but primarily affects cattle (Zajac and Conboy, 2017; Hendrix and Robinson, 2016).

The louse fly or sheep ked (Melophagus ovinus) is a fly without functional wings that is a permanent parasite of the host (sheep). Transmission is via direct contact and the larvae that are produced by the females pupate on the skin of the host. These parasites cause significant damage to the skin and make the hide unsuitable for leather production.
Blow flies or fly strike occurs from the maggots of the families Calliphoridae and Sarcophagidae. The larvae of these flies are not obligate parasites but the adults are attracted to the odor of decaying organic material and deposit their eggs on carrion. Larvae feed primarily on necrotic material and when development is complete they leave the host and pupate. These parasites can cause serious damage to animals and in large numbers can cause tissue destruction, toxaemia and even death. Screwworms are parasites of major veterinary importance. There is the New World screwworm Cochliomyia hominivorax and the Old World screwworm Chrysomya bezziana (Zajac and Conboy, 2017; Hendrix and Robinson, 2016). Adult females deposit eggs on the host and larvae feed on living tissue. Screwworm infestation is a serious disease that can rapidly lead to the death of the host.

The final group of flies that will be discussed are biting flies. These flies have common names such as horse fly (Hematopota), deer fly (Chyrsops), mosquito, black fly, sand fly, tsetse fly (Glossina), horn fly (Haematobia irritans), stable fly (Stomoxys calcitrans) and midge (Culicoides). Biting flies lay eggs that hatch into larvae which is then followed by pupation and subsequently the emergence of an adult. It is the adult that feed on the blood of animals in some cases it is both sexes whilst in other only the females are blood sucking (e.g. mosquitoes). Biting flies are of veterinary importance as they are disease vectors for protozoa, helminths and viruses (Zajac and Conboy, 2017; Hendrix and Robinson, 2016). Additionally, biting can cause irritation, dermatitis and in massive attacks can lead to toxaemia and even death of the animal.

\subsubsection{Wild Neo-tropical animals}

The parasitology books that were reviewed made no specific mention of Ectoparasites that affects nondomesticated neo-tropical species. However, some texts that were written on the biology and management of these unique species did give mention to some Ectoparasites, the type of host and the effects on the host. In the capybara (Hydrochoerus hydrochaeris), Amblyomma cajennense have been identified (Cueto, 2013). Capybaras may become anaemic and this tick also transmits Rickettsia rickettsia where the capybara is considered a reservoir host. Sarcoptic mange (Sarcoptes scabei) has been found to affect capybaras and other South American rodents (Agouti paca, Dasyprocta leporina, Myocastor coypus and Myoprocta spp.)(Cueto, 2013; Pachaly et al., 2001). Clinical signs seen in the capybara for Sarcoptic mange are similar to those identified above in the domesticated species.

In contrast, South American marsupials have been found with a wide array of ecto-parasites but clinical parasitism is rare in these animals. This may be due to their biological adaptations to their neo-tropical environment (Fowler, 2001). The collared peccary (Tayassu tajacu) have been seen with numerous ecto-parasites. These include Amblyomma spp. Sarcoptic mange and fleas. However, only mild signs of dermatitis are noted with these animals (Margarido and Mangini, 2001). Ectoparasites such as fleas, flies, ticks and lice have been found in south American deer. The treatments of these parasites are similar to 
what is seen with domesticated ruminant. Some species of ecto-parasites identified include Ctenocephalides felis, Dermatobia hominis, Cochliomyia spp., Amblyomma spp., Haemaphysalis spp. and Ixodes spp. (Duarte et al., 2001).

\section{Blood parasites}

\subsection{Dogs and cats}

Parasites within this category can be divided in protozoa and helminth. The protozoa parasites can be further divided in hemogregraine, piroplasm and hemoflagellate. The helminth that infects the circulatory system is nematodes. Usually animals are infected by these parasites through an intermediate host having a blood meal on the primary host. The only exception is with Hepatozoon spp. where the blood parasite is acquired through ingestion of the infected tick, ticks acquire the infection during feeding.

The gamonts of Hepatozoon spp. are found in polymorphonuclear leukocytes while the meronts can be found in various organs such as skeletal muscle. Hepatozoon spp. causes severe disease with myositis, periosteal bone proliferation but is some cases may be subclinical. Hepatozoon spp. are classified as hemogregraine. The first piroplasm under investigation is Babesia spp. (B. canis and $B$. gibsoni). It is found in the red blood cells of dogs and acquired through the brown dog tick (Rhipicephalus sanguineus) in America, Dermacentor reticularus in Europe and Haemophysalis leachi in Africa. Clinical signs may range from mild to severe with anemia, haemolytic crisis and multi-organ failure. The second piroplasmsis is Cytauxzoon felis where merozoites are found in red blood cells and schizonts are found in histiocytes. Transmission occurs from blood feeding activity of Dermacentor variabilis. This disease is highly pathogenic in cats and cause anaemia, icterus, fever, hepatomegaly and splenomegaly.

Haemoflagellates which infects dogs and cats are Leishmania spp. and Trypanosoma cruzi. These two parasites are zoonotic and can cause Leishmaniasis (visceral and cutaneous form) and Trypanosomiasis in humans. The species of Leishmania includes $L$. donovani, L. tropica, L. infantum, L. chagasi, L. braziliensis and L. mexicana. These parasites have indirect life cycles with sand-flies (Phlebotomus spp. and Lutzomyia spp.) as the intermediate host. In dogs the disease is usually asymptomatic but the skin and visceral organs can be involved. Detection occurs when amastigotes are found in macrophages in stained fine needle aspirates from lymph nodes or impression smears of skin lesions. In contrast, Trypanosoma cruzi is highly pathogenic and can cause enlargement of visceral organs as well as acute or chronic cardiac disease. This parasite is transmitted via the faeces of the kissing bug (Triatomids) during blood feeding of the definitive host. The parasite enters through the mucous membranes or from the Triatomid bite wound. Trypanomastigotes are found in the blood but amastigotes and epimastigotes can be found in skeletal muscles, reticuloendothelial cells and other tissues.

Nematodes which are found in the blood of cats and dogs are Dirofilaria immitis and Acanthocheilonema reconditum.
The common name for $D$. immitis is heartworm, it is transmitted by the mosquito and microfilaria are found in the circulatory system but the adult worms are found in the pulmonary arteries and right ventricle. Diagnosis can be confirmed using antigen kits but microfilaria can be found on blood smears but this is less accurate. Heartworm is a major disease for dogs and can lead to right sided heart failure in chronic cases. In cats, signs are usually subclinical but serous clinical disease may manifest as a chronic respiratory or gastrointestinal disease. Acanthocheilonema reconditum are acquired from fleas and lice. Arthropod ingests microfilaria in blood or skin of infected canids and transmits the disease to other dogs on a subsequent feeding. This disease is usually subclinical but is important as it can lead to a misdiagnosis of a heartworm infection.

\subsection{Livestock and horses}

Piroplasms that are of clinical importance to ruminants include Babesia spp. and Theileria spp. Babesia spp. are found on red blood cells whilst Theileria spp. can be found on red blood cells and lymph nodes. Babesia spp. which infects cattle are $B$. bovis, $B$. divergens, $B$. bigemina and B. major; sheep and goats are infected by $B$. ovis and B. motasi. Tick species such as Ixodes and Rhipicephalus acts as the intermediate host, with the ticks acquiring the parasites through feeding. Animals affected by this parasite develop anaemia, haemoglobinuria and fever. Theileria spp. of importance are T. parvum (East and South Africa) and T. annulata (Europe and North Africa). Rhipicephalus and Hyalomma ticks are the intermediate host and become infected upon ingestion of the hosts' red blood cells. Affects animals show lymphadenopathy, depression and nasal discharge.

Trypanosoma spp. is a pathogen of high clinical importance to livestock and horses as it can cause anaemia followed by fever, oedema and weight loss. High mortality rates can be seen with flocks that are infected with this parasite. There are several species which affects livestock, these include; T. congolense, T. brucei brucei, T. simiae, $T$. vivax, T. evansi and T. melophagium. These flagellates can be found in the bloodstream of infected animals but $\mathrm{T}$. brucei can also be found in other tissues. Trypanosoma spp. is transmitted through biting flies such as the Tsetse fly and tabanid fly.

Babesia spp. found in horses are B. caballi and B. equi. These parasites are found on red blood cells and are transmitted by ticks such as Rhipicephalus, Hyalomma and Dermacentor. Horses infected with Babesia suffer from anaemia, haemoglobinuria and oedema and in some cases paralysis and incoordination. In livestock Seteria spp. are the only nematode where the microfilaria are found in the blood and the adults are found in the peritoneal cavity. This pathogen is transmitted by the mosquito and is not of any clinical significance unless the parasite migrates to essential organs (such are the nervous system).

\subsection{Birds}

There are three blood parasites of clinical significance in birds. These are Leucocytozoon spp., Haemoproteus spp. and Plasmodium spp. L. simondi parasitizes domestic 
and wild ducks globally. L. smithi affects both wild and domestic ducks and turkey in north America and Europe. Finally, L. caulleryi affects chickens in India. Leucocytozoon is transmitted by black flies (Simulium spp,) and gamonts (Macro and micro) can be found in leukocytes and erythrocytes. Clinical signs of disease can vary amongst birds but animals are usually lethargic and emaciated. On farm, acute or chronic fatalities may be seen (Urquhart et al., 1996).

Haemoproteus spp. is a haemoprotozoan parasites that affects avian species worldwide. $H$. columbae and $H$. sacharovi affects doves and pigeons, $H$. meleagridis affects domestic and wild turkeys and $H$. nettionis affects wild and domestic duck and geese. The parasite can be found in erythrocytes and its transmitted from an intermediate host (hippoboscid flies, midges, deer fly) through blood feeding. Infections are usually asymptomatic (Zajac and Conboy 2017; Hendrix and Robinson 2016). The last of the three blood parasites that affects avian species is Plasmodium. Plasmodium is also a hemoprotozoa which affects erythrocytes as well as other tissues within the bird. Birds become infected when mosquitoes acquire a blood meal. Most species are non-pathogenic but pathogenic species cause anaemia with high fatality rates (Zajac and Conboy 2017; Hendrix and Robinson 2016).

\subsection{Wild Neo-tropical animals}

South American marsupials are host to various blood parasites. These include Rickettsia rickettsia, Trypanosoma cruzi and Leishmania brazilienses. R. rickettsia and T. cruzi are usually asymptomatic but $L$. braziliensis may develop dermatological ulcers on the base of the tail (Fowler 2001). South American rodents (D. leporina, A. paca, $H$. hydrochaeris, etc.) have been found with protozoan blood parasites such as Babesia spp., Trypanosoma spp. and Leishmania spp. However, the author failed to identify the clinical presentation of these organisms on these rodents (Pachaly et al. 2001).

Blood parasites noted in peccaries (Tayassu tajacu) were Eperythrozoon spp. and Trypanosoma cruzi (Margarido and Mangini, 2001). In Neo-tropical deer (Cervidae family) Anaplasma marginale is infected naturally and are carriers of the infection (Duarte et al., 2001). Trypanosomes have been found in deer species in South America. Some of the species identified are T. vivax, T. equiperdum, T. theileri and T.evansi (Duarte et al., 2001). Information on the blood parasites of neo-tropical animals were near to none in the parasitology texts. However, information was available on some of the pathogens that affects neo-tropical animal in texts on wildlife management.

\section{Endoparasites}

\subsection{Dogs and cats}

Parasites that inhabit the gastrointestinal tract are broken into protozoan and helminth parasites. These parasites can have direct or indirect life cycles; they shed their eggs or oocysts in the faeces. The infection form which is consumed by the definitive host is the sporulated oocyst and infective larvae (Zajac and Conboy, 2017). Information was given on the gastrointestinal parasites that affect dogs, cats, pigs, horses, ruminants, camelids, rabbits, rodents and birds. All animals mentioned previously were domesticated animals with no information on the gastrointestinal parasites of wild neo-tropical animals.

Helminths and protozoa which infected cats and dogs were discussed in great detail. Protozoa parasites included Isospora spp., Toxoplasma gondii, Neospora caninum, Sarcocystis spp., Cryptosporidium felis, C. canis, Trichomonas foetus and Giardia intestinalis (Zajac and Conboy, 2017). Toxoaplasma gondii and Neospora caninum was found in the intestines and other tissues with transmission occurring for ingestion of cysts contained in bradyzoites of the tissues of the intermediate host. The above protozoa are located in the gastrointestinal tract and oocysts are detected through centrifugation or simple faecal floatation (Zajac and Conboy, 2017).

Some protozoa have specific floatation techniques and solutions to give the most accurate results. Oocysts of Cryptosporidium spp. can be detected by acid-fast or other stains of faecal smear. Sheather's sugar floatation, faecal antigen and molecular diagnostic procedures can be used for identification. Trichomonas foetus cannot be detected by used of faecal floatation but commercial PCR is available and direct saline smears of fresh faeces (Zajac and Conboy, 2017). Giardia intestinalis cysts may be detected by faecal floatation using $33 \% \mathrm{Zn} \mathrm{SO}_{4}$ centrifugation, other floatation solutions cause rapid distortion (Zajac and Conboy, 2017).

Helminths in dogs and cats are classified taxonomically into nematodes, trematodes and cestodes according. Nematodes found within dogs and cats include Ancyclostoma spp., Uncinaria stenocephalus, Toxocara canis, T. cati, T. leonina, Baylisascaris procyonis, Trichuris vulpis, Capillaria spp., Aonchotheca putorii, Physaloptera spp., Spirocerca lupi, Strongyloides steracoralis, Aelurostrongylus abstrusus, Crenosoma vulpis, Angiostrongylus vasorum, Filaroides osleri and Ollulanus trichuspis. These nematodes also classified as hookworms (Ancyclostoma spp. and Uncinaria stenocephalus), roundworms (Toxocara canis, T. cati and T. leonina), racoon roundworm (Baylisascaris procyonis), whipworm (Trichuris vulpis), lungworm (Capillaria spp.), oesophageal worm (Spirocerca lupi) and intestinal thread worm (Strongyloides leonina) (Zajac and Conboy, 2017; Hendrix and Robinson, 2016; Urquhart et al., 1996).

The nematodes listed above were found in the lungs and gastrointestinal tract. Eggs from the above species are passed out into the digestive tract directly or indirectly when it is coughed up by the respiratory tract. Some parasites were also mentioned to have infected wild animals and raccoons such as Physaloptera spp. and Baylisascaris procyonis. However, the location of the wild animals was not identified (Zajac and Conboy, 2017). Diagnostic tests used in the identification of the above nematodes include faecal floatation and faecal sedimentation. All the nematodes mentioned above faecal floatation can be used in identification. However, Physaloptera spp. and Spirocerca lupi have can only be identified using faecal sedimentation.

Cestodes (tapeworms) of dogs and cats usually cause subclinical signs. The tapeworms mentioned below have 
dogs and cats as their primary host and the adults are found in the gastrointestinal tract. Identification of the eggs can be done via faecal floatation. However, the eggs are passed out of the host as worm segments, once these packets are ruptured the eggs can be floated (Urquhart et al., 1996). The following are tapeworms that are found in dogs and cats; Dipylidium caninum, Taenia spp. (T. taeniaeformis in cats, $T$. pisiformis, T. multiceps, T. hydatigena and T. ovis in dogs), Echinococcus spp. (E. granulosus and E. multilocularis in dogs and wild canids), Mesocestoides spp. (M. corti, M. lineatus and M. variablis in dogs, cats, wild mammals and birds), Diphyllobothrium latum and Spirometra spp. (S. mansonoides, S. erinaceieuropaei in cats, dogs and wild animals) (Zajac and Conboy, 2017; Hendrix and Robinson, 2016).

Trematodes (flukes) commonly seen in dogs and cats are found in the liver (bile duct), intestines as well as mesenteric blood vessels. Identification is usually done through faecal sedimentation due to the weight of the eggs (Zajac and Conboy, 2017; Hendrix and Robinson, 2016). The life cycles of trematodes are indirect but these ones mentioned below have dogs and cats as their primary host. Alaria spp., Paragonimus kellicotti, Heterobilharzia americana, Nanophyetus salmincola, Platynosomum concinnum and Cryptocotyle lingua have been indentified in dogs and cats but most cause subclinical disease (Zajac and Conboy, 2017; Hendrix and Robinson, 2016).

\subsection{Ruminants and camelid}

Protozoa parasites that affect ruminants and camelids can be caused by three organisms. These are Eimeria spp., Cryptospordium parvum and Giardia intestinalis. The Eimeria spp. can be further divided into species which affects bovine, ovine and caprine. E. bovis, E. zuernii and E. alabamensis cause clinical disease in bovine. In goats, $E$. airlongi, E. caprina, E. ninakohlyakimovae and E. christenseni causes clinical disease. Whilst in sheep E. ovinoidalis, E. ahsata and E. bakuensis causes disease. Eimeria spp. are very host specific therefore the identification of the species becomes crucial (Urquhart et al., 1996).

There are numerous nematodes that cause diseases ruminant and pseudo ruminant animals. These nematodes can be formed into a group as seen with Strongylids. The nematodes that belong to this group are Ostertagia, Haemonchus, Cooperia, Trichostrongylus, Teladorsagia, Mecistocirrus, Bunostomum, Chabertia, Camelostrongylus, Lamanema, Nematodirus and Oesophagostomum (Zajac and Conboy, 2017; Hendrix and Robinson, 2016).

Other nematodes which are present in the digestive tract that are of clinical significance are Trichuris spp. (whipworm), Capillaria spp., Strongyloides papillosum, Toxocara vitulorum (roundworm) and Skrjabinema spp. (pinworm). Those found in the lungs are Protostrongylus spp., Muellerius capillaris and Dictyocaulus spp. (Zajac and Conboy, 2017; Hendrix and Robinson, 2016). The identification of these nematodes can be done through faecal floatation. However, identification of species must be done using the Baermann's technique and faecal egg culture.

Cestodes such as Moneizia spp. and Thysanosoma spp. are found in the gastrointestinal tract for ruminants. Moneszia spp. such as $M$. benedeni and $M$. expansa are found in the small intestines but Thysanosoma is found in the bile duct (Zajac and Conboy, 2017; Hendrix and Robinson, 2016). Ruminant trematodes include; Fasciola hepatica (liver fluke), Paramphistomum spp. (rumen fluke), Dicrocoelium dendriticum, Eurytrema pancreaticum and Shistosoma spp. These flukes can be found in the bile duct (F. hepatica, $D$. denriticum), rumen (Paramphistomum spp.), pancreatic duct (E. pancreaticum) and portal mesenteric veins (Shistosoma spp.) (Urquhart et al., 1996).

\subsection{Swine}

Protozoan parasites that can be found in the digestive system of pigs include: Eimeria spp., Isospora suis and Balantidium coli. Eimeria spp. such as E. scabra, E. spinose and $E$. debleiki are usually asymptomatic. B. coli cause little clinical effects on pigs. However, I. suis clinically affect neonatal piglets causing diarrhoea and can cause death in severe cases (Zajac and Conboy 2017; Hendrix and Robinson, 2016).

Nematodes which are commonly found in swine can be classified based on their location within the host. The small intestine is home to Macracanthorhynchus hirudinaceus (thorny-headed worm), Ascaris suum (roundworm) and Strongyloides ransomi (threadworm). Physocephalus sexalatus, Ascarops strongylina and Hyostrongylus rubidius (red stomach worm) are found in the stomach. Nematodes of the large intestine include Trichuris suis (whipworm) and Oesophagostomum spp. (nodular worm) (Zajac and Conboy, 2017; Hendrix and Robinson, 2016). In the lungs, Metastrongylus spp. can be found in the bronchi and bronchioles. These eggs are passed in the faeces of pigs when they are coughed up from the lungs.

Trematodes are rarely found in pigs. However, Fasciola spp., Eurytrema pancreaticum, Dicrocoelium dendriticum and Schistosoma spp. have been found in pigs. Swine which are raised on pastures are can be found with these parasites.

\subsection{Horse}

Protozoan parasites that affect the gastrointestinal tract of equid species include; Eimeria leuckarti, Giardia intestinalis and Cryprosporidium spp. These organisms infect the small intestines of these animals. However, infection with these parasites appears to have little clinical significance (Urquhart et al., 1996). Parasitic helminths cause enormous damage to the gastrointestinal tract of horses. Equine strongylid parasites are a group of nematode parasites that causes diarrhoea, colic and hypoproteinemia in affected horses. Nemarodes which are present in this group include Strongylus vulgaris (large strongyles), Cyathostoma spp. (small strongyles) and Trichostrongylus axei (small strongyles). This group of parasites are found in the caecum and colon except T. axei which is found in the stomach (Zajac and Conboy, 2017; Hendrix and Robinson, 2016).

Other nematodes found in horses include; Parascaris equorum (roundworm), Strongyloides westeri (threadworm), Oxyuris equi (pinworm), Habronema microstoma, $H$. muscae, Draschia megastoma and Dictyocaulus arnfieldi (lungworm). These parasites are found in the stomach 
( $H$, microstoma, H. muscae, and D. macrostoma), small intestines (P. equorum, S. westeri), large intestines (E. equi) and lungs (D. arnfieldi) (Zajac and Conboy, 2017; Hendrix and Robinson, 2016). Tapeworms that affect horses include Anaplocephala perfoliata, A. magna and Paranaplocephala mamilliana. However, these parasites rarely cause clinical diseases in equids.

\subsection{Bird}

Protozoan parasites in birds are of great economic importance. This is due to the fact that they cause tremendous damage to the digestive system of these animals and can quickly lead to mortality. Coccidia which affect these species can be divided into Eimeria spp. and Isospora spp. Eimeria spp. is commonly seen in poultry, Galliformes and Columbriformes. Whilst, Isospora spp. are seen in Passeriformes, Psittaciformes and Piciformes (Zajac and Conboy, 2017; Hendrix and Robinson, 2016). Cryptosporidium spp. which are zoonotic are found in birds. $C$. baileyi and C. meleagridis are found in the respiratory, digestive or urinary tracts depending upon the host species infected. Gastrointestinal protozoan flagellates include Trichomonas spp., Cochlosoma spp., Histomonas spp., Giardia spp., Hexamita spp. and Chilomastix spp. These parasites can be found in the upper digestive system ( $T$. gallinae), caecum and liver (Histomanas spp.) and intestines (Giardia spp., Cochlosoma spp. and Hexamita spp.) (Zajac and Conboy, 2017).

Nematodes found in avian species include Ascaridia spp. (roundworm), Capillaria spp., Trichostrongylus tenuis, Amidostomum spp., Syngamus spp. (gapeworm), Dispharynx spp., Tetrameres spp., Echinuria spp., Subulura spp. Cheiliospirura and Heterakis spp (caecal worm). These parasites can cause mild to severe diseases in avian species. Usually fluke infections are of low pathogenicity (Zajac and Conboy, 2017). However, in large numbers clinical signs may manifest in birds. Flukes that are of veterinary importance for avian species include Echinostoma spp., Echinoparyphium spp. and Prostogonimus spp. The adult flukes may be found in various body systems. Tapeworms are also found in the digestive tract of birds but infections are usually asymptomatic. Davainea spp., Choanotaenia spp., Raillietina spp. and Hymenolepsis spp. are found in the small intestine. $D$. proglottina and $R$. echinobothrida can cause severe enteritis and death in domestic poultry. The thorny headed worms of birds are Filicollis spp. and Polymorphus spp. Heavy infections may cause diarrhoea and debilitation in wild birds (Zajac and Conboy, 2017).

\subsection{Exotic and Laboratory animals}

In this section parasites of rodents and rabbits will be discussed. Eimeria spp. which is of clinical importance to rabbits is E. stiedae which is found in the bile ducts. Usually Eimeria spp. are non-pathogenic but with pathogenic species (e.g. E. stiedae) clinical signs related to gastrointestinal irritation are seen. Rodents can also be infected with protozoa like Cryptosporidium and Giardia which is of zoonotic significance. Nematodes of clinical importance in rodents are Sypacia obvelata and Aspicularis tetraptera. These are considered the pinworms of mice and rats respectively. It is found in the large intestines both rats and mice. The pinworm of rabbits is Passalurus ambiguous, this worm is found in the caecum. Most of the cases of pinworms are subclinical (Zajac and Conboy, 2017).

There are other nematode that affects rabbits, guinea pigs, rats and mice which will be highlighted. Paraspidodera uncinata and Heterakis spumosa is found in the caecum of guinea pigs and rats respectively. Most cases are subclinical and are usually found in wild rats and guinea pigs reared on dirt floors (Zajac and Conboy, 2017). The stomach of rabbits and rodents are predilection sites for a variety of nematodes. These include Obeliscoides cuniculi (rabbits) and Graphidium strigosum (rabbits). Nippostrongylus braziliensis was found the small intestines of rats and Heligmosomoides polygyrus found in the small intestines of mice.

There is a small amount of cestodes that utilized rodents and rabbits as their primary host. These are Hymenolepis nana (rodents and humans) and Cittotaenia spp. (rabbits). Hymenolepis nana is a cestode of zoonotic importance as it can infect humans and the adults are found in the small intestines (Zajac and Conboy, 2017; Hendrix and Robinson, 2016).

\subsection{Wild Neo-tropical animals}

Several endoparasites have been identified in wild Neo-tropical rodents but little clinical effect seen. The information on these endoparasites was found in wild life management text and not in veterinary parasitology texts. Endoparasites include: Ascaris, Ancyclostoma, Trichuris, Capillaria, Paraspidodera uncinata and Longistriata brevispicula (Pachaly et al., 2001). Neo-tropical marsupials such as Didelphis marsupialis insularis have numerous internal parasites but clinical parasitism is rare in these animals. Parasites such as Eimeria spp. have been found in the digestive tract of these animals (Fowler, 2001).

With respect to Neo-tropical ungulates such as the red brocket deer and collared peccary numerous parasites have also been found in their digestive tract. Collared peccary have been found with Balantidium coli in their digestive tract. B. coli is zoonotic and persons may become infected if they are in close contact with these animals in captivity (Margarido and Mangini, 2001). Neo-tropical deer species have been found with numerous endoparasites similar to domestic ruminants. Most of these parasites have been mentioned above in the section on domestic ruminants and will not be reiterated at this point. However, these animals can be managed and treated for these Endoparasites in a similar way as domestic ruminants (Duarte et al., 2001).

\section{Conclusion}

Numerous parasites have been identified on both domesticated and wild animals. However, the major focus of the parasites mentioned in veterinary texts used in teaching Trinidadian students was on domesticated animals. Wild neo-tropical animals are becoming more important as a source of food and utility and some attention must be paid to the parasites in which they can harbour. Future work must be done to include these non-domesticated animals into the revised texts or the construction of new 
texts material on the parasites of wild neo-tropical animals with the potential for domestication.

\section{References}

CUETO, G.R., 2013. Diseases of Capybara. In: J. MOREIRA, K. FERRAZ, E. HERRERA and D. MACDONALD, eds. Capybara: biological use and conservation of an exceptional neotropical species. New York: Springer Science and Business Media. http://dx.doi. org/10.1007/978-1-4614-4000-0_9.

DUARTE, J.M.B., MERINO, M.L., GONZALEZ, S., NUNES, A.L.V., GARCIA, J.M., JUÁN SZABÓ, M.P., PANDOLFI, J.R., ARANTES, I.G., NASCIMENTO, A.A., MACHADO, R.Z., ARAÚJO JÚNIOR, J.P., CATÃO-DIAS, J.L., WERTHER, K., GARCIA, J.E., GIRIO, R.J.S., and MATUSHIMA, E.R., 2001. Order Atriodactyla, Family Cervidae (Deer), biology and medicine. In: M.E. FOWLER and Z.S. CUBAS, eds. Biology, medicine and surgery of South American wild animals. Iowa: Iowa State University Press.

FOWLER, M.E. and CUBAS, Z.S., eds., 2001. Biology, medicine and surgery of South American wild animals. Iowa: Iowa State University Press. http://dx.doi.org/10.1002/9780470376980.

FOWLER, M.E., 1998. Medicne and surgery of South American Camelids. Hoboken: Wiley-Blackwell.

FOWLER, M.E., 2001. Order Marsupialia (Opossums): biology and medicine. In: M.E. FOWLER and Z.S. CUBAS, eds. Biology, medicine and surgery of south american wild animals. Iowa: Iowa State University Press. http://dx.doi.org/10.1002/9780470376980.

HENDRIX, C. and ROBINSON, E., 2016. Diagnostic parasitology for veterinary technicians (6th ed.). USA: Elsiever.

JONES, K.R. and GARCIA, G.W., 2018. Gastrointestinal parasites of domesticated animals introduced into the Neo-tropics (New
World Tropics). Concepts Dairy Veterinary Science, vol. 1, no. 2, pp. 1-17. http://dx.doi.org/10.32474/CDVS.2018.01.000110.

JONES, K.R. and GARCIA, G.W., 2019. Endoparasites of domesticated animals that originated in the neo-tropics (new world tropics). Veterinary Sciences, vol. 6, no. 1, pp. 24. http://dx.doi.org/10.3390/ vetsci6010024. PMid:30845667.

JONES, K.R., LALL, K.R. and GARCIA, G.W., 2019. Endoparasites of selected native non-domesticated mammals in the neotropics (New World Tropics). Veterinary Sciences, vol. 6, no. 4, pp. 87. http://dx.doi.org/10.3390/vetsci6040087. PMid:31671585.

KRULL, W.H., 1968. Notes in parasitology. Manhattan: University Press of Kansas.

LAPAGE, G., 1954. Veterinary parasitology. Edingburg: Oliver and Boyd.

MARGARIDO, T.C.M. and MANGINI, P.R., 2001. Order Atriodactyla, Family Tayassuidae (Peccaries), biology and medicne. In: M.E. FOWLER and Z.S. CUBAS, eds. Biology, medicine and surgery of South American wild animals. Iowa: Iowa State University Press.

PACHALY, J.R., ACCO, A., LANGE, R.B., NOGUEIRA, T.M.R., NOGUEIRA, M.F. and CIFFONI, E.M.G. 2001. Order Rodentia (Rodents); Biology and Medicine. In: M.E. FOWLER and Z.S. CUBAS, eds. Biology, medicine and surgery of South American wild animals. Iowa: Iowa State University Press.

SOULSBY, E.J.L., 1982. Helminths, arthropods and protozoa of domesticated animals (7th ed.). London: Baillière Tindall.

URQUHART, G.M., ARMOUR, J., DUNCAN, J.L., DUNN, A.M. and JENNINGS, F.W., 1996. Veterinary parasitology. 2nd ed. Cambridge, UK: Blackwell Science.

ZAJAC, A.M. and CONBOY, G.A., 2017. Veterinary clinical parasitology. Hoboken: John Wiley \& Sons. 